\title{
Differences on lymphocyte subset counts according to the degree of overweight-obesity in adolescents from Madrid. The AFINOS Study
}

\author{
A. M. Veses ${ }^{1}$, S. Gómez-Martínez ${ }^{1}$, F. Perez De Heredia ${ }^{1}$, B. Zapatera ${ }^{1}$, O. L. Veiga ${ }^{2}$ and A. Marcos ${ }^{1}$ \\ ${ }_{1}^{1}$ Immunonutrition Research Group, Department of Metabolism and Nutrition, Institute of Food Science, Technology and \\ Nutrition, Spanish National Research Council (CSIC), Madrid, Spain and ${ }^{2}$ Department of Physical Education, Sport and \\ Human Movement, Faculty of Education and Teaching Training, Autonoma University of Madrid, Madrid, Spain
}

Reports of diverse relationships between body mass index and the organism's defense system in humans ${ }^{(1)}$ have driven us to question whether changes in peripheral leukocyte counts exist in relation to overweight and obesity status in adolescents.

The purpose of this analysis was to study possible differences on lymphocyte subset counts according to the degree of overweight and obesity in a sub-sample of adolescents participating in the AFINOS study ("Physical activity as a preventive agent in the development of overweight, obesity, allergies, infections and cardiovascular risk factors in adolescents").

A sub-sample of 187 adolescents ( 96 females) from the city/the community of Madrid (from a total of 2,000 participants enrolled in the AFINOS study) was studied. Body mass index was calculated and the adolescents were classified into two groups: overweight/obese and non-overweight, according to Cole's cut-off points. Lymphocyte subsets $\left(\mathrm{CD} 4{ }^{+}, \mathrm{CD} 8{ }^{+}, \mathrm{CD} 3^{+}, \mathrm{CD} 19^{+}, \mathrm{CD}_{16}{ }^{+} 56^{+}, \mathrm{CD}^{+}{ }^{+} \mathrm{CD} 45 \mathrm{RO}^{+}\right.$, $\mathrm{CD}^{+}{ }^{+} \mathrm{CD} 45 \mathrm{RA}^{+}, \mathrm{CD}^{+}{ }^{\mathrm{CD}} 45 \mathrm{RO}^{+}, \mathrm{CD}^{+} \mathrm{CD} 45 \mathrm{RA}^{+}, \mathrm{CD}^{+} \mathrm{CD}^{+} 5 \mathrm{RO}^{+}, \mathrm{CD}^{+}{ }^{+} \mathrm{CD} 45 \mathrm{RA}{ }^{+}$) were determined by flow cytometry. The Student's- $t$ test was used to analyze the differences on lymphocyte subset counts between genders and between body mass index groups; the latter analysis was performed separately in boys and girls.

On average, boys had significantly higher counts of $\mathrm{CD} 16^{+} 56^{+}(p<0.05)$ and $\mathrm{CD} 19^{+}(p<0.001)$ than girls. The prevalence of overweight was $31.9 \%$ in males and $21.9 \%$ in females. In males, no significant differences were found in lymphocyte subset counts between overweight/obese and non-overweight groups, whereas in females, values for $\mathrm{CD} 3{ }^{+}, \mathrm{CD}^{+} \mathrm{CD}^{+} \mathrm{RO}^{+}, \mathrm{CD}^{+} \mathrm{CD} 45 \mathrm{RO}{ }^{+}$and $\mathrm{CD}^{+}{ }^{+} \mathrm{CD} 45 \mathrm{RO}^{+}$were higher in the overweight/obese group $(p<0.05)$.

These results indicate that there is a significant relationship between overweight and immune cell counts in adolescents, which seems to be gender-specific.

1. Ilavská S, Horváthová M, Szabová M et al. (2012) Hum Immunol 73, 480-485. 